\title{
Seasonal variation of hydrochemical characteristics of open-pit groundwater near a closed metalliferous mine in O'Kiep, Namaqualand Region, South Africa
}

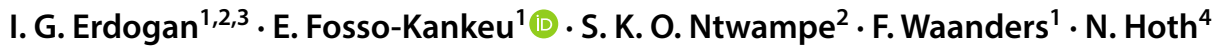

Received: 22 April 2018 / Accepted: 17 February 2020

(c) Springer-Verlag GmbH Germany, part of Springer Nature 2020

\begin{abstract}
In this study, the hydrochemical characteristic changes of open-pit groundwater (OPGW) near a closed metalliferous mine proposed for drinking and irrigation usage were investigated. Water samples from an OPGW in O' Kiep were collected in April (dry season) and August (wet season), 2017. Data analysis methods, such as the coefficient of variation, correlation coefficient, piper trilinear plot analysis and sodium adsorption ratio (SAR) among others were used to assess of the seasonal variation in the OPGW quality. The hydrochemical characteristics of the OPGW were also compared with drinking water guidelines. Based on the results, it was evident that the OPGW quality varied seasonally. The most abundant cation and anions were $\mathrm{Ca}^{2+}$ and $\mathrm{SO}_{4}{ }^{2-}$, with recorded concentrations of 631 and $6020 \mathrm{mg} / \mathrm{L}$, (dry season); 541 and $4450 \mathrm{mg} / \mathrm{L}$ (wet season), respectively. The OPGW was relatively rich in $\mathrm{SO}_{4}{ }^{2-}>\mathrm{Cl}^{-}>\mathrm{Mg}^{2+}>\mathrm{Ca}^{2+}>\mathrm{Na}^{+}>\mathrm{K}^{+}$during the dry season; however, these cations and anions were reduced during the wet season with $\mathrm{Cl}^{-}$and $\mathrm{Na}^{+}$subsequently increasing. PHREEQC indicated that cation exchanges played a significant role in the OPGW chemistry with $\mathrm{Sb}$ and $\mathrm{Ca}$ appearing to be the minerals with the highest precipitation potential followed by $\mathrm{Cu}_{7} \mathrm{~S}_{4}$ and Blaubleil, respectively. Covellite, $\mathrm{CdSe}_{2}$ and NiSe were likely to be in equilibrium while $\mathrm{Ca}_{3} \mathrm{Sb}_{2}$ will remain in a dissolution state. Furthermore, the seasonal fluctuation in the OPGW quality characteristics was attributed to the water table level fluctuations and the water quality did not satisfy the guidelines stipulated by the South African National Standard, SANS241-1 (2015) and World Health Organisation, WHO (2011). The trilinear piper plot classified the OPGW into three types: $\mathrm{Ca}^{2+}-\mathrm{Mg}^{2+}-\mathrm{Cl}^{-}-\mathrm{SO}_{4}{ }^{2} ; \mathrm{Ca}^{2+}-\mathrm{Mg}^{2+}-\mathrm{F}^{-}$; and $\mathrm{Ca}^{2+}-\mathrm{Mg}^{2+}-\mathrm{SO}_{4}{ }^{2-}$. Overall, the SAR values were within the permissible levels for irrigation purposes; however, long-term use of the OPGW might be detrimental for plant growth.
\end{abstract}

Keywords Arid region $\cdot$ Closed metalliferous mine $\cdot$ Hydrochemical characteristics $\cdot$ Groundwater $\cdot$ O'Kiep

E. Fosso-Kankeu

Elvis.FossoKankeu@nwu.ac.za

1 Water Pollution Monitoring and Remediation Initiatives Research Group (WPMRIRG) in the CoE of C-Based Fuels School of Chemical and Minerals Engineering, North-West University, Potchefstroom, South Africa

2 Bioresource Engineering Research Group (BioERG), Cape Peninsula University of Technology, Cape Town, South Africa

3 Faculty of Engineering and the Built Environment, Chemical Engineering Department, Cape Peninsula University of Technology, Cape Town, South Africa

4 Institute of Mining and Special Civil Engineering, Technische Universität Bergakademie Freiberg, Saxony, Germany

\section{Introduction}

In South Africa (SA), the vicinity of operating mines to water sources culminates in the contamination of such sources, including groundwater due to the exposure of different geochemical profiles of underground aquifers by elements mined. The variance in the hydrochemical profile of groundwater differs for each location, thus depends on climatic and seasonal changes, including the geological profile of the area (Jonch-Clausen 2004; DWA 2004). Mining activity can also change the hydrochemical profile of groundwater. Contaminated groundwater has been one of the challenges faced by communities in SA as groundwater is considered as one of the primary water resources for developmental activities, however, its quality is adversely affected or degraded as a result of anthropogenic activities 
that introduce pollutants into the groundwater. Overall, groundwater contamination is usually irreversible (Rajendran et al. 2019; Abdelgawad 2005).

Environmental challenges arising from mining activities are receiving increasing attention in SA generally; however, less so in small former copper mining areas, such as O'Kiep, which was considered in the eighteenth century to be the richest copper mining area in the world (Cairncross 2004). Currently, this town is experiencing various challenges, such as poor drinking water quality. In O' Kiep, the mining of copper left a legacy of metalliferous waste, such as tailings, waste rock and contaminated soils within the vicinity of this town. Generally, such mining activities are known to pollute both the immediate environment and ground and/or surface water resources. This can culminate in water shortages, even if water is available from various sources(Singh and Kamal 2015) it might be contaminated.

Groundwater is a key component of the water resources of SA. As such, it can provide much of the water required for households, especially since the country's surface water resources are unevenly distributed and cannot cope with growing demand (Bredenhann and Braune 2000). In a report of surface and groundwater assessment in Namaqualand, an area which includes O'Kiep, the levels of several contaminants in the groundwater from some boreholes were higher than the SANS Class II drinking water limits and therefore the water was not suitable for human consumption (Holmes 1995). Additionally, the analysis also indicated that, the groundwater quality exceeded the recommended values for livestock use, as set out in South African water quality guidelines for agricultural use and livestock (DWAF 1996, Holmes 1995), with mining activity suspected to be a source of the contamination.

The geochemistry of the minerals mined in the O'Kiep area is such that sulphidic ores are the dominant minerals in the copper-rich ore body of the area (Faris et al. 2017). Copper sulphide ores that are common in the O'Kiep area are bornite $\left(\mathrm{Cu}_{5} \mathrm{FeS}_{4}\right)$, chalcopyrite $\left(\mathrm{CuFeS}_{2}\right)$, chalcocite $\left(\mathrm{C}_{2} \mathrm{~S}\right)$, digenite $\left(\mathrm{Cu}_{9} \mathrm{~S}_{5}\right)$, enargite $\left(\mathrm{Cu}_{3} \mathrm{AsS}_{4}\right)$ and pyrite $\left(\mathrm{FeS}_{2}\right)$ (Hangone et al. 2005). These are the primary constituents in the ore body that facilitate acid rock drainage, sulphide geological material oxidation and the transportation of potentially toxic elements (PTEs) by leaching (Fosso-Kankeu et al. 2015, 2017; Munyai et al. 2016). Dissolved minerals in the surface water can be transported and thus pollute groundwater when the water table is high. Sulphide containing ores are known to produce acid when exposed to oxygen and water (Plumlee 1999). The oxidation of pyrite and copper sulphide ores in tailings and mine dumps is due to weathering as described by Antonijević et al. (2008). Generally, such weathering can enhance the mobility of PTE species which can contaminate groundwater.
The national state on water resources report by the DWA (2011-2012) on climatic conditions, indicated a reduction in rainfall and an increase in evaporation due to higher temperatures that impacted on the SA's scarce water resources. Additionally, the groundwater in O' Kiep is highly susceptible to high evaporation rates. Natural factors that could influence changes in the quality of the groundwater in O' Kiep include the host rock, precipitation, evapotranspiration and acid rock drainage (ARD) formation (Van Dyk et al. 2008). Under excessive evaporative conditions, groundwater salinity displays a cumulative tendency to increase (Abiye and Leshomo 2013). Furthermore, groundwater arid and semiarid environments are subjected to periodic salinisation due to high evaporation rates and low rainfall (Nakwafila 2015). The understanding of groundwater hydrochemical characteristics is a vital factor in determining its safety for use in domestic and agricultural activities. Therefore, it was necessary to investigate the seasonal variation of the quality of an open-pit groundwater (OPGW) near a closed metalliferous mine. Earlier studies by Erdogan et al. (2017), carried out in this area, evaluated the hydrochemical characteristics of the OPGW quality. However, these studies did not attempt to assess the seasonal variation in the OPGW quality. Therefore, the objective of this study was to assess the seasonal variation of the OPGW quality, and to determine its suitability for drinking and irrigation purposes.

\section{Materials and methods}

\section{Site description}

O' Kiep is situated in Namaqualand, Northern Cape Province of South Africa (Cairncross 2004) with coordinates $\left[29^{\circ}\right.$ $\left.35^{\prime} 45^{\prime \prime} \mathrm{S} 17^{\circ} 52^{\prime} 51^{\prime \prime} \mathrm{E}\right]$. This town is $38.63 \mathrm{~km}^{2}$ in size with a reported population of approximately 6300 people in 2011 and is approximately $570 \mathrm{~km}$ from Cape Town. O'Kiep is characterised by an arid climate with no perennial river systems. The Lower Orange River (LOR) is the only perennial river, located some $150 \mathrm{~km}$ east of O'Kiep and it is a major source of piped drinking water supply for agricultural, domestic and industrial use for the town. The geometry of the aquifer systems in O'Kiep has been largely influenced by the underlying geology of metamorphic rocks, such as granites (Pietersen et al. 2009). The groundwater in the socalled Namaqualand aquifer occurs in the alluvial and crystalline basement rocks (Adams et al. 2003), with the Spektakel aquifer previously having supplied water to O'Kiep, Nababeep and Springbok. However, this was replaced by the water supply scheme from the LOR (Nuclear 2006) due to suspected contamination of the aquifer attributed to long-term copper mining and poor groundwater management practices. The hydrochemistry of groundwater in 
Namaqualand aquifer indicates dissimilar composition due to the ensuing complex geochemical processes as the chemistry is being controlled primarily by dissolution, redox reactions and mixing (Abiye and Leshomo 2013). A further source of water is an open-pit situated $1.1 \mathrm{~km}$ downstream from the closed O'Kiep metalliferous mine, which is filled with water.

\section{Sample collection}

Prior to the sample collection, permission was granted by the O'Kiep Copper Company and Namakhoi municipality for the purposes of this study. Samples $(n=10)$ in duplicate were collected from the open-pit $\left[29^{\circ} 35^{\prime} 55.1^{\prime \prime} \mathrm{S} 17^{\circ} 52^{\prime}\right.$ 47.6" E] (144 m width, $10 \mathrm{~m}$ depth), on the 5th of April 2017, a dry season (average temperature of $37^{\circ} \mathrm{C}$ ) and on the 8th of August 2017, a wet season (average temperature of $16^{\circ} \mathrm{C}$ ) with a minimal rainfall occurring in the area on the day of sampling (Accuweather 2017). The samples were collected between 7 and 11 a.m. for both seasons. The sampling points were randomly selected due to soil erosion and restricted access to the open-pit. Multi-parameter instruments were calibrated prior to field measurement usage according to the national field water measurement standards (Gibs and Wilde 2007; Wilde and Radtke 1998), with polypropylene sample bottles $(500 \mathrm{~mL})$ being used for sample collection. The sampling bottles were thoroughly cleaned and rinsed in dilute $0.5 \mathrm{M} \mathrm{HCL}$, prior to rinsing with sterile deionized water. The bottles were air-dried and stored closed to prevent pollution prior to sample collection. Samples were collected around the open-pit in duplicate at depths between 1 and $9.5 \mathrm{~m}$ (dry season) and 1 and $11 \mathrm{~m}$ (wet season) using a HydraSleeve ${ }^{T M}$ "No-Purge" groundwater sampler according to the method described by Trick et al. (2008), with GPS coordinates being recorded at the sampling points as shown in Fig. 1, which indicates the sampling area, and potential sources of contaminants, i.e. stockpiled metalliferous waste and tailings storage facility.

During sampling, the following physical parameters were quantified onsite, using an EXSTIK II ${ }^{\circledR}$ EC500 and an EXSTIK II ${ }^{\circledR}$ CA895, for dissolved oxygen (DO): pH, temperature, electrical conductivity (EC), redox potential (ORP), salinity and total dissolved solids (TDS). The instruments were calibrated prior to sampling using standard procedures

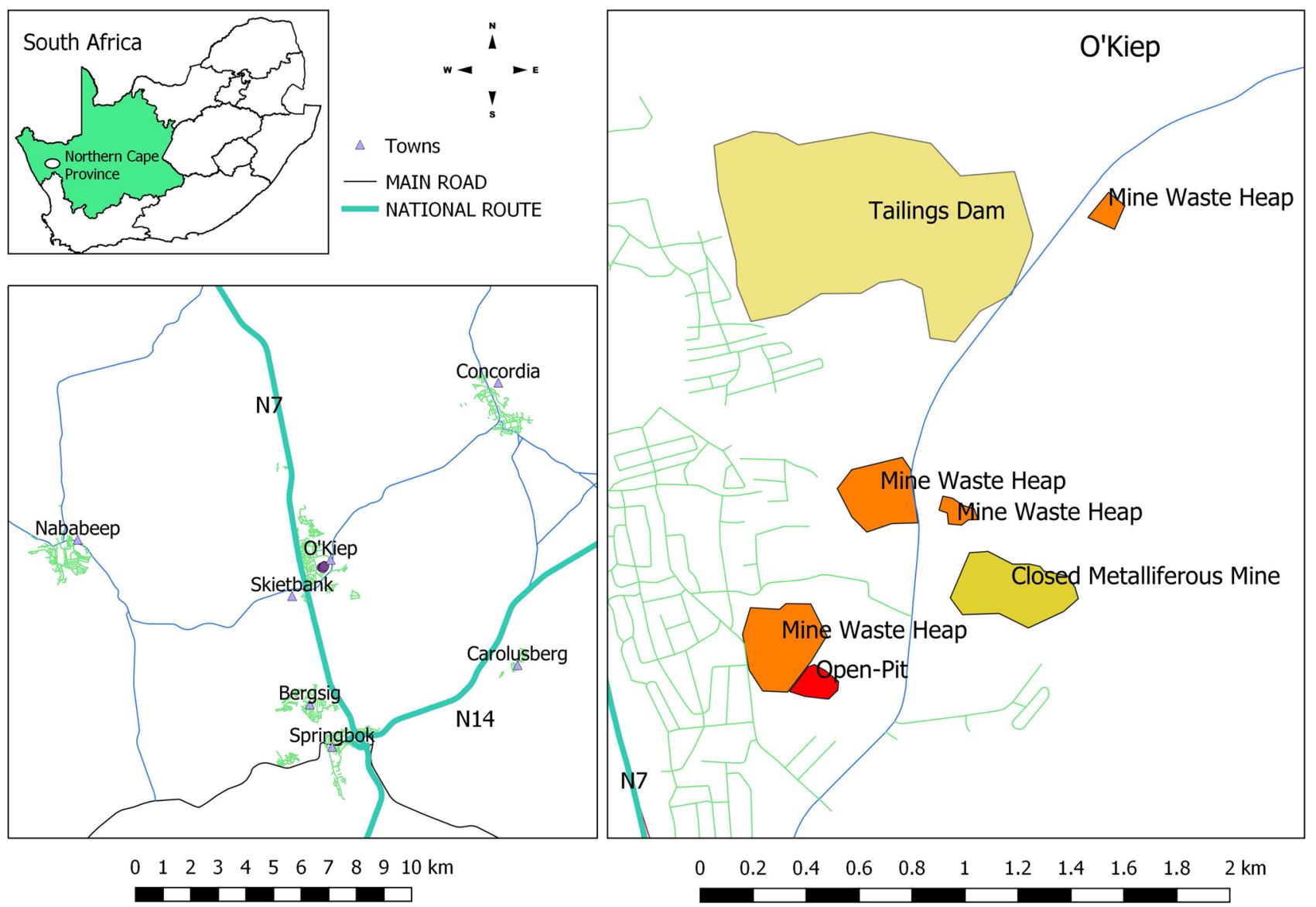

Fig. $1 \mathrm{XXX}$ 
as described by Shah and Mjalli (2014). The temperature was measured in situ to minimise atmospheric variations according to the method described by Weaver et al. (2007a) and Sundaram et al. (2009). Samples were also filtered through a $0.45-\mu \mathrm{m}$ cellulose membrane filter, using a handvacuum pump, into polypropylene sampling bottles (Ball et al. 1999, APHA 2005). The unfiltered $100 \mathrm{~mL}$ per sample were digested with technical grade nitric acid $(0.2 \mathrm{M})$. Unless otherwise stated, all reagents used, were of analytical grade, while standardised methods of analysis were used (APHA 2005).

All samples were stored in cooler boxes with ice to ensure preservation during transportation to the laboratory thereby further analyses were performed. All samples were analysed without dilution. Analyses performed included quantification of anions, cations, PTEs and chemical oxygen demand, using UV-Vis spectrophotometer, high-performance liquid chromatography (HPLC), inductively coupled plasma coupled either with a mass spectrometer (ICP-MS) or an optical emission spectrometer (ICP-OES) at an external South African National Accreditation System (SANAS) accredited laboratory.

\section{Data analysis}

Multivariate statistical analysis using Microsoft Office Excel $2016^{\circledR}$,was used for the assessment of the OPGW quality focusing on the coefficient of variation (CV) (Stanković et al. 2015), correlation analysis (CA) and the trilinear piper plot.

\section{The coefficient of variation and correlation analysis}

The quality variability of the OPGW can be measured by determining fluctuations in the water table and can be expressed as a coefficient of variation (Stanković et al. 2015). The contributing aquifer can have a dynamic range of groundwater levels as they discharge and recharge seasonally (Quevauviller et al. 2009). The CV was determined using Eq. (1) (Abdi 2010):

$\mathrm{CV}=\frac{\text { Standard Deviation }}{\text { Mean }} \times 100$.

The first step prior to the multivariate statistical analyses is to reduce data sizes by eliminating the variables that do not provide important information of groundwater quality. Therefore, parameters indicating a $<5 \% \mathrm{CV}$ were considered almost constant and thus excluded from the statistical analyses (Pacheco Castro et al. 2018; Güler et al. 2002).

$\mathrm{CA}$ is a bivariate technique used to define the degree of relation between two hydrochemical parameters. CA has been broadly used as an unbiased method for drawing meaningful information in the analysis of water quality variation (Singh et al. 2005; Selvakumar et al. 2017).

\section{Geochemical modelling}

A thermodynamic model with a mathematical program was applied to determine ion interactions (Leonard and Pierre 2013). Dissolution-precipitation processes, saturation indices (SI) of some mineral phases were calculated with PHREEQC Version 3 software (US Geological Survey) that elucidate speciation and reaction mechanisms (Zhu and Anderson 2002; Parkhurst and Appelo 1999). Furthermore, speciation, solubility, reaction and inverse mass balance modelling were activated to complete the process. The MINTEQ.V4.DAT database was used for the ion interaction approach. The redox potential (pe) value was determined using a portable ORP instrument (Hi 98190). The Ag/ $\mathrm{AgCl}$ electrode reference was used as a comparison with the hydrogen scale (Nordstrom and Wilde 2005). Additionally, a PHREEQC batch reaction model was used to perform irreversible and equilibrium reactions (see Eqs. 2 and 3).

$E h=\mathrm{ORP}+\mathrm{E} \Theta$,

$\mathrm{Pe}=E h \frac{\mathrm{mv}}{59.2} \mathrm{mV}$

\section{Sodium adsorption ratio}

The sodium adsorption ratio (SAR) is a measure of the suitability of water for irrigation purpose. The formula for calculating the sodium adsorption ratio is presented in Eq. (4) (Manoj et al. 2017):

$\mathrm{SAR}=\frac{\mathrm{Na}^{+}}{1 / 2\left[\mathrm{Ca}^{2+}+\mathrm{Mg}^{2+}\right]}$

\section{Results and discussion}

Table 1 presents the seasonal variation of the OPGW. The OPGW temperature showed a wide range of variation from an average of $23.0^{\circ} \mathrm{C}$ (dry season) to $14.4{ }^{\circ} \mathrm{C}$ (wet season), which reflected a seasonal change in atmospheric air temperature. The $\mathrm{pH}$ values of OPGW samples during dry and wet season were slightly acidic, at $\mathrm{pH} 4.5-5.2$ and 3.7-3.8, respectively. The $\mathrm{pH}$ values for the water sampled in both seasons were not within the permissible limit for drinking water according to SANS241-1 (2015) and WHO (2011). This includes the low average DO concentrations in both dry $(0.9 \mathrm{mg} / \mathrm{L})$ and wet season $(0.1 \mathrm{mg} / \mathrm{L})$ samples, indicative of the anaerobic conditions of the OPGW. A decrease in COD 


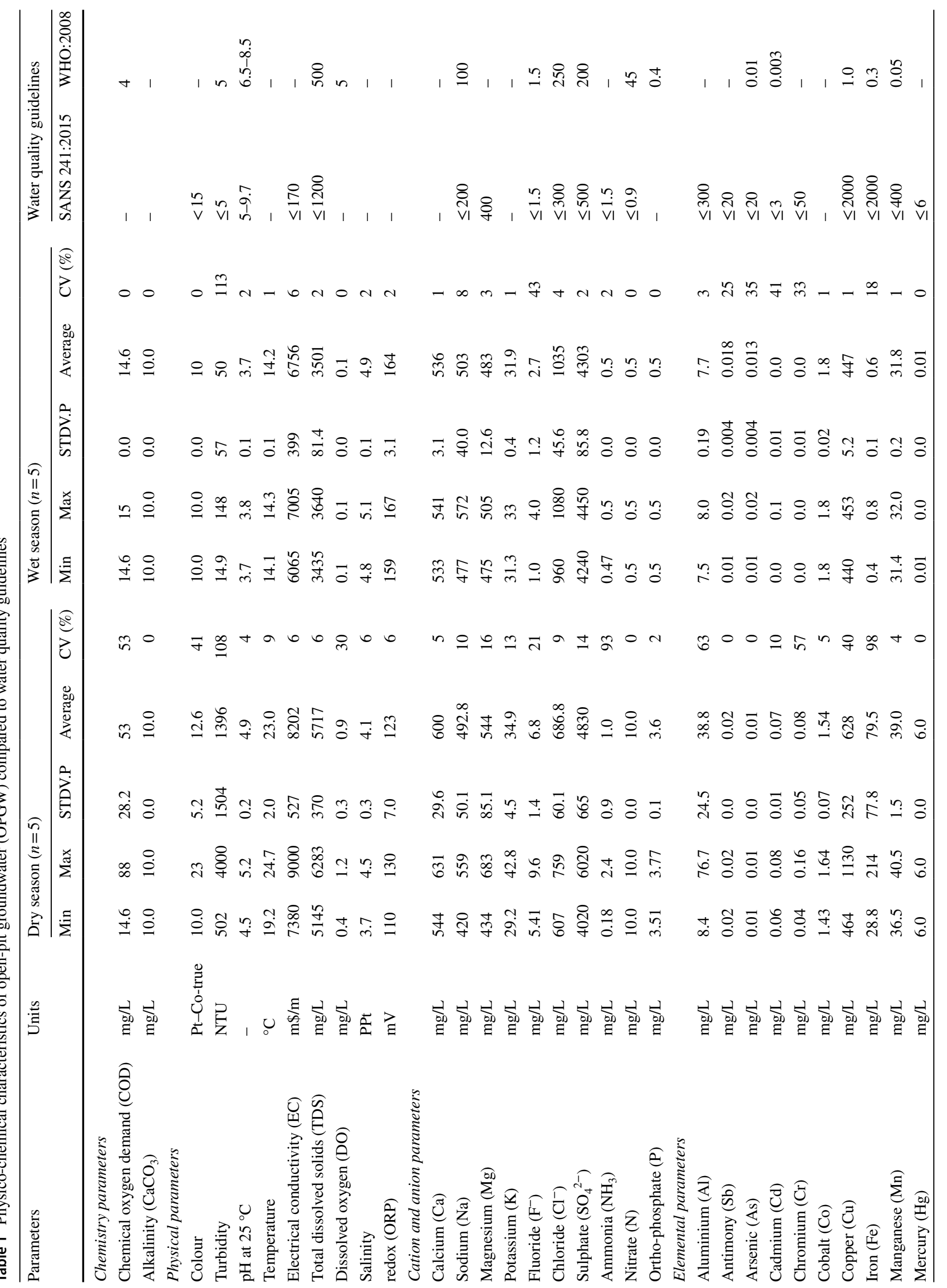




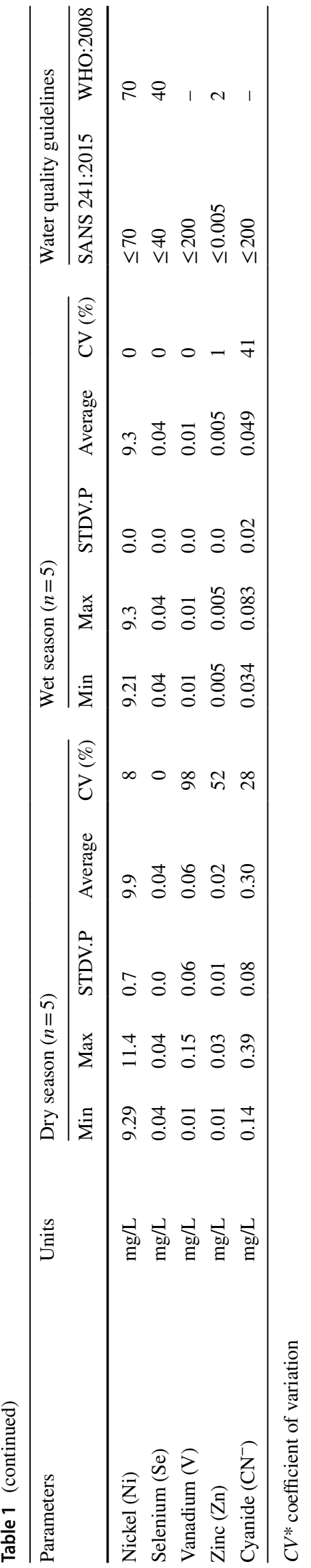

ranging from 53 to $15 \mathrm{mg} / \mathrm{L}$ for both seasons indicated low organic matter in the OPGW; thus, an insignificant organic matter contamination; albeit COD can also be reduced due to chemically induced chelating during thermal oxidation in slight acidic water (Osborne et al. 2009). Overall, the CODs were greater than the WHO (2011) water quality guideline value of $4.0 \mathrm{mg} / \mathrm{L}$. Generally, DO has a significant effect upon groundwater quality since it regulates the solubility of many trace metals and limits the bacterial metabolism of organic compounds by aerobic bacteria. Some bacteria use DO as part of their metabolism in certain cases, facilitating the oxidation of ammonia, hydrogen sulphide, organic carbon and other reductants (Weaver et al. 2007b). The DO content also indicated changes in the redox state and microbial activity of the water samples (Pretorius et al. 2008) as ORP increased from $123.1 \mathrm{mV}$ (dry season) to $164 \mathrm{mV}$ (wet season).

The OPGW salinity was noticed to increase from $4.1 \mathrm{~g} / \mathrm{L}$ (dry season) to $4.9 \mathrm{~g} / \mathrm{L}$ (wet season). The OPGW salinity is a significant groundwater quality indicator, which is controlled by many factors such as aquifer mineralogy, and topography even mobility of PTEs into the water from the surface of the contaminated area as a result of mining activity (Praveena et al. 2011). Rabbani et al. (2010) also reported that saline water starts to infiltrate inland during the wet season, with Yan et al. (2015) concluding that groundwater salinity varies with the fluctuation of groundwater level. According to the Northern Cape Department of Environmental Affairs and Nature Conservation (Goegap Nature Reserve report 2018), most of the rainfall in O'Kiep varies between 100 and $300 \mathrm{~mm}$ per year; however during sampling in August 2017, only $2 \mathrm{~mm}$ of rain was recorded. Furthermore, the TDS and EC slightly decreased from $5717 \mathrm{mg} / \mathrm{L}$ and $8202 \mathrm{mS} / \mathrm{m}$ (dry season) to $3501 \mathrm{mg} / \mathrm{L}$ and $6756 \mathrm{mS} / \mathrm{m}$ (wet season), respectively. EC of the OPGW is a direct function of its TDS and indicates concentration of soluble salts in the groundwater (Harilal et al. 2004; Purandara et al. 2003). These values were not within the allowable limits by SANS241-1 (2015) and WHO (2011). The OPGW contained high dissolved solids content which may be caused by human activity (Ramakrishnaiah et al. 2009).

For different seasons, the groundwater turbidity varied from a maximum of 4000 NTU (dry season) to a minimum of 148 NTU (wet season). High turbidity values during the dry season were due to clay and silt-sized particles present at the edges of the open-pit. The turbidity values for both seasons were above the drinking water quality limit stipulated by SANS241-1 (2015). The causes of water turbidity are diverse; and in most cases, the suspended and dissolved solid particles contribute to high turbidity, with some particles being pneumatically transported into receiving water especially during the dry season. However, turbidity can also indicate the presence of dissolved hazardous PTEs and 
the proliferation of microbial contaminants. The less turbid water (NTU 148) obtained during wet season could be an indication of acquifer recharge (Mativenga and Marnewick 2018). The CV for turbidity increases were from $108 \%$ (dry season) to $113 \%$ (wet season) with both seasons having a CV greater than 100\%, an indication of variability (Ma et al. 2011). This was an indication that environmental alterations might critically affect the OPGW in this arid area. Similarly, an alkalinity of $10 \mathrm{mg} / \mathrm{L}$ for both seasons was observed, with sulphate reduction being hypothesised as contributory factor (Whitworth et al. 2014), which is also an indication of sustained microbial activity and slow weathering of noncarbonated rocks, such as the igneous granite and gneiss (Pretorius et al. 2008).

The ions concentration in the OPGW samples varied in both seasons. The most abundant cation and anions were $\mathrm{Ca}^{2+}$ and $\mathrm{SO}_{4}{ }^{2-}$. The high level of $\mathrm{Ca}^{2+}, \mathrm{Mg}^{2+}$ and $\mathrm{SO}_{4}{ }^{2-}$ concentration was associated with the oxidation and weathering of sulphide minerals, which may be due to dissolution of gypsum- and calcium-bearing minerals (Selvakumar et al. 2017). Similar results were obtained in a study of Abiye et al. (2018) through which hydrogeochemical parameters of the groundwater system in the Namaqualand region were studied. The relative ionic abundance in the OPGW at the O'Kiep copper mine area showed that the trend for cation availability in the following sequence $\mathrm{Ca}^{2+}>\mathrm{Na}^{+}>\mathrm{K}^{+}>\mathrm{NH}_{3}$ and $\mathrm{SO}_{4}{ }^{2-}>\mathrm{Cl}^{-}>\mathrm{NO}_{3}{ }^{-}>\mathrm{F}^{-}>\mathrm{PO}_{4}{ }^{3-}$ for anions. An increase in $\mathrm{Na}^{+}, \mathrm{Cl}^{-}, \mathrm{Ca}^{2+}$ and $\mathrm{SO}_{4}{ }^{2-}$ was an indication of the dissolution of quaternary sand, scree rubble and sandy soil deposits in which minerals, such as anhydrite, halite and gypsum occur.

The $\mathrm{CV}$ of the abundant $\mathrm{Cl}^{-}$and $\mathrm{SO}_{4}{ }^{2-}$ anions decreased during the wet season from 9 to $4 \%$ and from 14 to $2 \%$, respectively. On the other hand, $\mathrm{F}^{-}$had a lower variation in the dry season (21\%) albeit higher in the wet season (43\%). Fluoride is a major component of fluorite $\left(\mathrm{CaF}_{2}\right)$, an additional mineral in granites. Dissolution of such minerals can constitute a major source of $\mathrm{F}^{-}$in groundwater (Edmunds and Shand 2009; Reddy et al. 2010). Additionally, more people in nearby areas in Namaqualand suffer from tooth decay, and decolouration assumed to be due to high concentration of $\mathrm{F}^{-}$. The high $\mathrm{F}$ concentration is typical for groundwater in granitic aquifers (Abiye et al. 2018).

$\mathrm{Al}, \mathrm{Cr}, \mathrm{Cd}, \mathrm{Cu}, \mathrm{Fe}$ and $\mathrm{Zn}$ all decreased from dry season to wet season from 63 to $3 \%, 57$ to $33 \%, 5$ to $1 \%, 40$ to $1 \%$, 98 to $1 \%$ and 52 to $1 \%$, respectively. However, the Sb, As, $\mathrm{Cd}$ and $\mathrm{CN}^{-}$increased to $15,35,41$ and $41 \%$, respectively. This was attributed to natural seasonal groundwater table fluctuations (Rijal et al. 2010). When the OPGW pH is low, the higher the mobility of $\mathrm{Sb}, \mathrm{As}, \mathrm{Cd}$ and $\mathrm{CN}^{-}$; thus, mobilisation in the groundwater a phenomena linked to the geologic setting of the study area, which is further influenced by the geochemistry of the mine waste, mine tailings which contaminates the immediate environment in the study area (Erdogan et al. 2017, 2018; Moncho et al. 2017). Additionally, geochemical processes controlled the mobilisation of $\mathrm{Sb}$ and As (Ramos et al. 2014). Aquifers in the Northern Cape, Namaqualand, are mostly assumed to be affected by natural conditions with only seasonal trends responsible for water level fluctuations. Depending on the aquifer type including rainfall can have a more significant influence on the groundwater quality (Adams et al. 2003; Van Dyk et al. 2008). Some aquifers are susceptible to contamination from surface sources. Fractured aquifers also allow rapid migration of contaminants via a preferred pathway, culminating in the potential to contaminate vast areas along the fracture network (Adams et al. 2004). The topography in this region is defined as a flat terrain with isolated mountains and hills. The observed hydraulic head and elevation data gathered from the hydrocensus indicate that the groundwater level in Namaqualand is related to its topography (Roets 2008; Ferreira et al. 2015). During the raining season, water can flow along the hydraulic gradient from the north-west to the south-east (Ferreira et al. 2015). The vegetation and flowers in this area bloom during the wet season, having adapted to this habitat with its alternating periods of exposure and inundation. From the results, it is observed that the maximum SAR value for the dry season was 22 , while for the wet season it was 25 , values which are within permissible levels for irrigation. However, as this groundwater is mildly acidic $(\mathrm{pH}=3.7-5.2)$ with very high salinity and $\mathrm{Na}^{+}$concentration levels was determined to be influenced weathered overburden in this mining area, thus continuous use of such water may cause a poor physical soil environment. A high amount of $\mathrm{Na}^{+}$concentration in irrigation water can adjust the osmotic pressure in the root zone of some plants, which can result in limiting the amount of water taken in by the plant which will consequently hinder plant growth (Ouyang et al. 2014; Selvakumar et al. 2017).

The OPGW had a high sulphate concentration of $4830 \mathrm{mg} / \mathrm{L}$ for the dry season and $4303 \mathrm{mg} / \mathrm{L}$ for the wet season. Also, there were elevated concentrations of dissolved trace elements in the dry season, in particular, $\mathrm{Cu}>\mathrm{Fe}>\mathrm{Al}>\mathrm{Mn}$. It was also noted that the higher the water table would rise due seasonal fluctuation during the wet season, the lower the values of trace elements $(\mathrm{Cu}>\mathrm{Fe}>\mathrm{Al}>\mathrm{Mn})$ and turbidity (Rao 2006). However, the PTEs, such as Al, $\mathrm{Sb}, \mathrm{As}, \mathrm{Cd}, \mathrm{Cr}, \mathrm{Co}, \mathrm{Cu}, \mathrm{Fe}, \mathrm{Mn}, \mathrm{Hg}, \mathrm{N}$, $\mathrm{Se}, \mathrm{V}, \mathrm{Zn}$ and $\mathrm{CN}$ were all within $\leq 20 \mathrm{mg} / \mathrm{L}$, a water quality guideline stipulated by SANS241-1 (2015), while As, Cu, $\mathrm{Fe}, \mathrm{Mn}$ were above $0.01 \mathrm{mg} / \mathrm{L}$ and not being within limits by the WHO (2011). The presence of As and Fe is an indication of oxidation of arsenic sulphides, such as arsenopyrite (FeAsS) and pyrite $\left(\mathrm{FeS}_{2}\right)$ in the groundwater (Zheng et al. 2004) and As also mobilises under anaerobic conditions 
as influenced by low DO concentrations (Tomlinson et al. 2017). However, it can be seen in Table 1 that low concentration of arsenic (As) was $0.01 \mathrm{mg} / \mathrm{L}$, albeit the nitrate concentration was $10 \mathrm{mg} / \mathrm{L}$ and $\mathrm{DO}$ of $0.9 \mathrm{mg} / \mathrm{L}$ (dry season) and $0.1 \mathrm{mg} / \mathrm{L}$ (wet season) were also observed. Additionally, a DO level less than $1.0 \mathrm{mg} / \mathrm{L}$ is an indication of anaerobic conditions in the OPGW (Dinicola 2006). Additionally, in the study of Leshomo (2011), As was rarely detected in the groundwater of Namaqualand area. Similarly, no uranium was detected in the OPGW for both seasons which could be due to the geology of the O'Kiep which comprise of granite (Clifford and Barton 2012). Moreover, uranium concentrations in groundwater in granite geological formations results in spatial distributions which are preferentially localized (Cho and Choo 2019). Similar results were also obtained in a Jurassic granite in Korea with low concentration of uranium (Cho and Choo 2019). Lowest uranium concentrations were also observed in groundwater characterized by iron and sulfate reducing conditions (Riedel and Kübeck 2018). These observation are further supported by the fact that the O'Kiep geology consists of thick sheet of granite gneiss up to $1500 \mathrm{~m}$ thick (Clifford and Barton 2012). Some physical parameters, cations, anions and trace elements, such as $\mathrm{pH}$, TDS, $\mathrm{Na}^{+}, \mathrm{Mg}^{2+}, \mathrm{K}^{+}, \mathrm{F}^{-}, \mathrm{Cl}^{-}, \mathrm{SO}_{4}{ }^{2-}, \mathrm{NO}_{3}{ }^{-}, \mathrm{PO}_{4}{ }^{3-}, \mathrm{Al}, \mathrm{Cu}$, $\mathrm{Fe}, \mathrm{Mn}$ and $\mathrm{Zn}$ would be much higher than those of natural groundwater associated geological formations, with the physical parameters being hypothesised to be due to leaching of elements from the surrounding waste rock mine dumps and tailings. Further study is; however, needed to better understand the mobility mechanism and sources of these PTEs occurring in various concentrations in the OPGW (Larkins et al. 2018). The chloride observed is a broadly distributed component in all types and forms of rocks (Pretorius et al. 2008). Its affinity towards sodium is high, with $\mathrm{Na}^{+}$and $\mathrm{Cl}^{-}$concentrations increasing during the wet season from an average of 493 to $503 \mathrm{mg} / \mathrm{L}$ and from 687 to $1035 \mathrm{mg} / \mathrm{L}$, respectively. According to Jeevanandam et al. (2007), the active dissolution of the halite in the OPGW was assumed to be the main cause of the high $\mathrm{Na}^{+}$and $\mathrm{Cl}^{-}$during the wet season. Soil permeability and porosity also have a key role in chloride concentration development (Ramakrishnaiah et al. 2009).

\section{Classification of the groundwater in O'Kiep}

The trilinear piper diagrams of the OPGW samples for both seasons are shown in Fig. 2. Groundwater in granitic rock is normally classified as $\mathrm{Na}-(\mathrm{Ca})-\mathrm{Cl}$ water-type and it is possibly controlled by mixing processes occurring between higher salinity groundwater $\mathrm{Na}-(\mathrm{Ca})-\mathrm{Cl}$ water-type and low salinity groundwater $\left(\mathrm{Na}-(\mathrm{Ca})-\mathrm{HCO}_{3}\right.$ water-type in the sedimentary rocks (Iwatsuki et al. 2005). Namaqualand experiences excessive evaporative conditions due to its aridity, as such the hydrochemical parameters increased, with the overall salinity being observed to be elevated. These changes in the groundwater quality might be primarily through parent rock weathering, dissolution and anthropogenic sources. It was presumed that natural geological sources could be the cause for the groundwater quality deterioration in the area, which is further driven by climatic changes (Abiye and Leshomo 2013). In the lower right of both triangles, for the dry and wet season, all samples show $\mathrm{SO}_{4}{ }^{2-}$ contents making up to $80 \%$ of the total anion load, indicating mixed water, without $\mathrm{Ca}^{2+}$ and $\mathrm{Mg}^{2+}$ cations exceeding $50 \%$ concentrations. When the concentrations of the ions were evaluated, it could be observed that the OPGW was relatively rich in $\mathrm{SO}_{4}{ }^{2-}>\mathrm{Cl}^{-}>\mathrm{Mg}^{2+}>\mathrm{Ca}^{2+}>\mathrm{Na}^{+}>\mathrm{K}^{+}$during the dry season. Additionally, an increase in $\mathrm{Na}^{+}$is likely to be attributed to silicate weathering (Brindha et al. 2017). An increase in $\mathrm{Cl}^{-}$concentrations indicated an anthropogenic effect or flow of water into a nearby aquifer (Kumar et al. 2006).

The groundwater has a distinct $\mathrm{Na}-\mathrm{Cl}$ character, mainly due to the geochemical composition of the crystalline rocks and alluvium from the Namaqua Metamorphic Complex (Titus 2002; Van Wyk et al. 2012; Braune and Xu 2010; Xu and Braune 2009) which primarily hosts groundwater in the study area. The $\mathrm{Na}-\mathrm{Cl}$ dominant rainfall, dissolution and leaching of evaporates can further augment the salinity of the groundwater (Van Wyk et al. 2012). The hydrochemistry of the area indicates dissimilar groundwater composition due to complex geochemical processes thereby groundwater flow takes place and the chemistry is controlled primarily by redox reactions, dissolution and mixing processes. Under excessive evaporative conditions due to climatic aridity, groundwater salinity increases (Abiye and Leshomo 2013). Anions $\mathrm{Cl}^{-}$and $\mathrm{SO}_{4}{ }^{2-}$ dominated the OPGW composition, a phenomena attributable to gypsum and pyrite oxidation including halite dissolution which was reported by Raith et al. (2003) in this area. These processes that might control the ion enrichment are dissolution, redox, evaporation and the residence time, which promote water-rock interaction. Additionally, the study area, generally, has poor groundwater quality due to geogenic sources of chemical constituents; especially, PTEs (Erdogan et al. 2017; Abiye and Leshomo 2013). The chemical composition of the OPGW indicated the dominance of the $\mathrm{Na}^{+}$and $\mathrm{Cl}^{-}$ions resulting in a $\mathrm{Na}-\mathrm{Cl}$ water type and similar results were obtained by Nakwafila (2015). Cation exchange for both dry and wet season may account for a reduction in the $\mathrm{Na}^{+}$concentration, and halite dissolution may account for high concentration of $\mathrm{Cl}^{-}$(Edet and Okereke 2002; Coyte et al. 2019). The OPGW is mostly classified into three types: $\left(\mathrm{Ca}^{2+}-\mathrm{Mg}^{2+}-\mathrm{Cl}^{-}-\mathrm{SO}_{4}{ }^{2-}\right)$; $\left(\mathrm{Ca}^{2+}-\mathrm{Mg}^{2+}-\mathrm{F}^{-}\right)$and $\left(\mathrm{Ca}^{2+}-\mathrm{Mg}^{2+}-\mathrm{SO}_{4}{ }^{2-}\right)$. The presence of these waters is due to the geology of O'Kiep and rockforming feldspars comprising of anorthosite, which contains amphibole (Ca-bearing) (Clifford and Barton 2012). The 


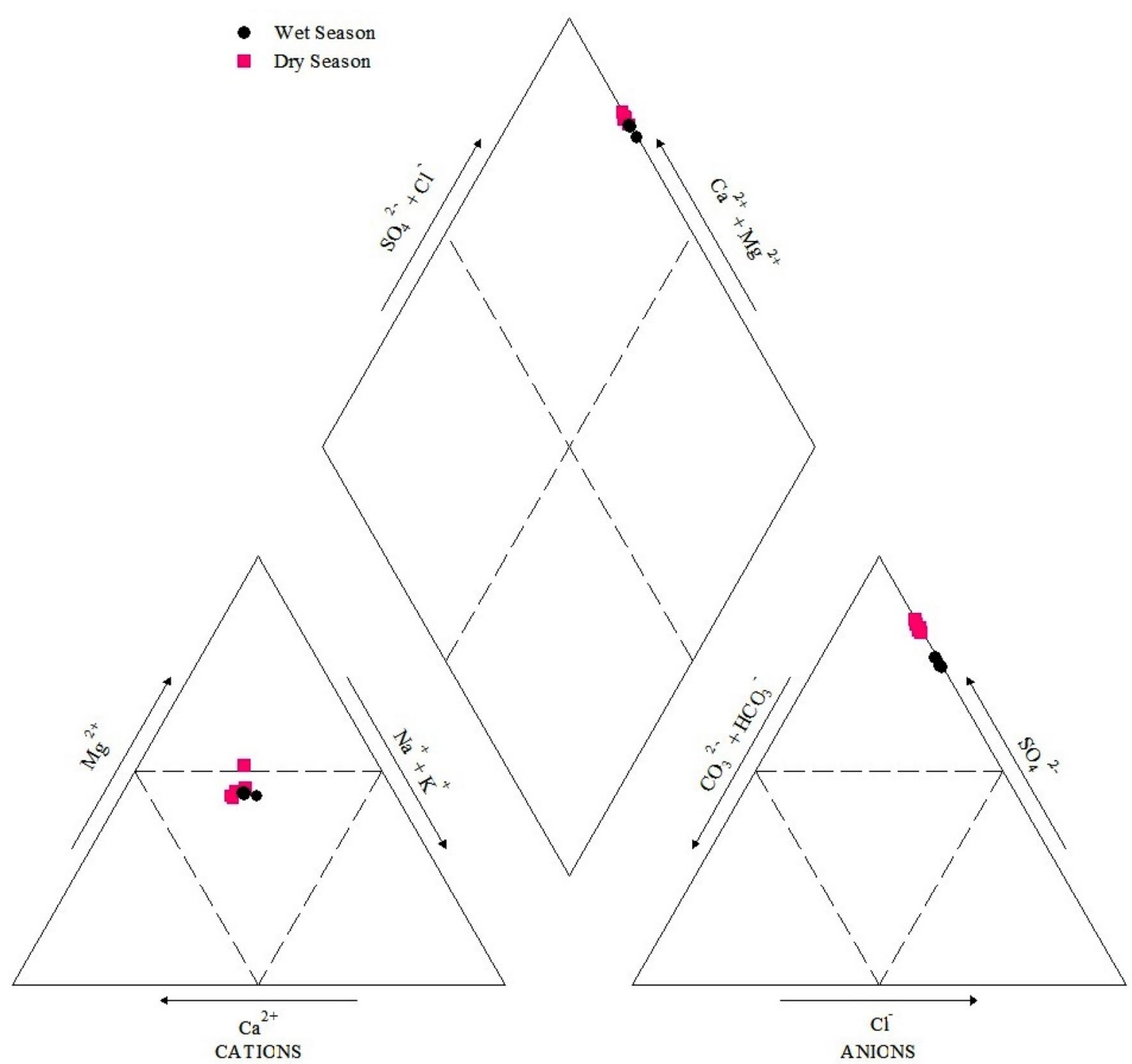

Fig. 2 Piper plot for both dry and wet seasons

$\mathrm{Ca}^{2+}-\mathrm{SO}_{4}{ }^{2-}$ type represents effects of ARD and sulphide minerals dissolution (Lee et al. 2005).

The geochemical modelling performed with PHREEQC hydrogeochemical modelling software indicated that the cation exchange plays a significant role in controlling the OPGW chemistry. Additionally, the data generated suggested that a number of geochemical factors are influential, i.e. temperature and $\mathrm{pH}$. Figure 3 enlists minerals that are partially in equilibrium and likely to precipitate during the contact between species. Chalcocite, $\mathrm{CuSe}$, Anilite and $\mathrm{Cu}_{3} \mathrm{Se}_{2}$ appeared to be the minerals with the greatest chance of precipitation followed by $\mathrm{Mn}_{2} \mathrm{Sb}$ and $\mathrm{AlSb}$, respectively. $\mathrm{Cu}_{3} \mathrm{Se}_{2}, \mathrm{FeSe}_{2}$ and $\mathrm{HgSb}$ had values greater than 10, whereas gypsum was likely to remain in equilibrium. Furthermore, $\mathrm{Cu}_{3} \mathrm{Se}_{2}$ is the most saturated and will likely lead to precipitation. $\mathrm{MnHPO}_{4}$ is labelled as the least saturated entity and has a smaller chance to precipitate than the others. Chalcocite is

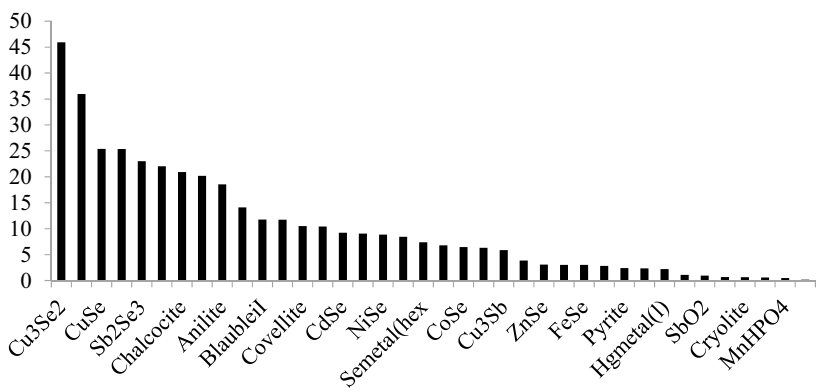

Fig. 3 The graph represents the mineral phases that could potentially precipitate during contact between species

known to contain the highest copper content (Beale 1985) and has a factor above 20. This translates to high copper deposits according to the model. High values do not always 
ensure precipitation and are highly dependent on the reaction of the mineral (Bosire et al. 2018). While several other minerals, such as halite will remain in a dissolution state (S1: Erdogan et al. 2019).

The temporal variations in hydrochemical characteristics corresponded well with fluctuations sampling locations. Interestingly, the OPGW sampling was $<10 \mathrm{~m}$ sample depth that the chemical evolution would be driven in part by biogeochemical reactions and evapoconcentration and rock-water interactions (Mladenov et al. 2014). Sample depth showed no significant seasonal variation during the monitoring period, implying that temporal variations in hydrochemical characteristics in the OPGW were affected by a different patterns, i.e. combined control by internal sources and surface contributions (Shen et al. 2019). The hydrochemical characteristics in both seasons $(<10 \mathrm{~m})$ showed insignificant seasonal variation, and any change in hydrochemical characteristics was inferred as being associated with anthropogenic activities.

\section{Evaluation of the groundwater quality in $0^{\prime}$ Kiep}

Ionic ratios of the open-pit groundwater are shown in Table 2. Hydrochemical indices assess the salinity and origin of the groundwater in the study area. Composition relations among dissolved species can reveal the source of solutes and the processes that generated the observed groundwater composition. Since $\mathrm{Na}, \mathrm{Ca}, \mathrm{Cl}, \mathrm{K}, \mathrm{Mg}, \mathrm{SO}_{4}$ were predominant ions in the OPGW, an analysis was made of stoichiometric relations that could account for the relative amounts of these ions. The average $\mathrm{Na} / \mathrm{Cl}$ ratios for both dry and wet seasons were approximately 0.7 and 0.5 , respectively, which is an indication of an alluvial aquifer since the ratio is less than 1 (Fisher and Mullican 1997). Overall, $\mathrm{Mg} / \mathrm{Ca}$, $\mathrm{Mg} / \mathrm{Ca}, \mathrm{Na} / \mathrm{Ca}, \mathrm{Ca} / \mathrm{Cl}, \mathrm{K} / \mathrm{Cl}$ and $\mathrm{Ca} / \mathrm{SO}_{4}$ ratios were all less than 2.0. According to the interpretation of these indices, the groundwater in the study appears to be slightly of inland origin, because groundwater under marine influence would have values of approximately 5 (Morrel et al. 1986). An exception whereby other processes such as cationic exchange intervene would then contribute to values of less than 4
(Nwankwoala and Udom 2011). Ratios of $\mathrm{Na} / \mathrm{Ca}$, indicating cation exchange reaction can show some mixed behaviour, but would mostly decrease with decreasing TDS during the wet season while an increase would be observed during the dry season, a good indicator revealing the salinization process in an aquifer (Nwankwoala and Udom 2011; Edet and Okereke 2002).

\section{Significance of the observed potentially toxic elements}

The correlation coefficients among various OPGW quality parameters were calculated and the values are given in Tables 3 and 4. The resultant CA illustrated that COD showed a good negative correlation $(-1.0)$ with $\mathrm{pH}$ and temperature, and a positive correlation $(+1.0)$ with EC, DO and ORP. The COD also showed a medium to weak correlation with turbidity, TDS and salinity. A significant positive correlation of $\mathrm{SO}_{4}{ }^{2-}$ was noticed with $\mathrm{Na}^{+}, \mathrm{Mg}^{2+}$ and $\mathrm{K}^{+}$; EC and TDS had good correlation between salinity and DO in the dry season. The good correlation of $\mathrm{Ca}^{2+}, \mathrm{Mg}^{2+}$, $\mathrm{Cl}^{-}$and PTEs (except $\mathrm{Fe}$ ) with $\mathrm{SO}_{4}{ }^{2-}$ indicated that most of the ions were involved in hydrochemical reactions and seasonal changes of groundwater in O' Kiep, which indicated a common origin for these ions (Sahraei Parizi and Samani 2013). The groundwater mineralisation is predominantly related to these components (Shorieh et al. 2015). Such a correlation was obvious as EC is normally a function of dissolved ionic species in groundwater (Appelo and Postma 2004). The COD and DO did not show any significant relationship with any of the tested parameters during the wet season. The $\mathrm{Cl}^{-}$also showed a significant positive relationship with $\mathrm{Na}^{+}, \mathrm{Mg}^{2+}$ and $\mathrm{K}^{+}$. The turbidity had good positive correlation with $\mathrm{pH}$, TDS, salinity and ORP during the wet season. In the present study, the significant correlations were observed among various metal pairs: $\mathrm{Cd}-\mathrm{Al}, \mathrm{Cr}-\mathrm{Al}$, $\mathrm{Cu}-\mathrm{Al}, \mathrm{Fe}-\mathrm{Al}, \mathrm{Mn}-\mathrm{Al}, \mathrm{Zn}-\mathrm{Al}$ and $\mathrm{CN}-\mathrm{Al}$ in the dry season, and between $\mathrm{Ni}-\mathrm{Al}, \mathrm{Zn}-\mathrm{Al}, \mathrm{Mn}-\mathrm{Al}, \mathrm{CN}-\mathrm{Al}, \mathrm{Ni}-\mathrm{Mn}$, $\mathrm{Zn}-\mathrm{Mn}, \mathrm{Zn}-\mathrm{Ni}, \mathrm{CN}-\mathrm{Zn}, \mathrm{CN}-\mathrm{Ni}, \mathrm{C}-\mathrm{Co}$ in the wet season. The correlation between metal pairs indicated the existence of a common source of origin for these PTEs, or mutual
Table 2 Ionic ratios of the open-pit groundwater

\begin{tabular}{llllllll}
\hline Units & \multicolumn{2}{l}{ Dry season $(n=5)$} & & \multicolumn{3}{l}{ Wet season $(n=5)$} \\
\cline { 2 - 3 } & Min & Max & Average & & Min & Max & Average \\
\hline $\mathrm{CaCO}_{3} / \mathrm{Cl}$ & 0.02 & 0.01 & 0.01 & & 0.01 & 0.01 & 0.01 \\
$\mathrm{Mg} / \mathrm{Ca}$ & 0.80 & 1.08 & 0.91 & & 0.89 & 0.93 & 0.90 \\
$\mathrm{Na} / \mathrm{Ca}$ & 0.77 & 0.89 & 0.82 & & 0.89 & 1.06 & 0.94 \\
$\mathrm{Na} / \mathrm{Cl}$ & 0.69 & 0.74 & 0.72 & & 0.50 & 0.53 & 0.49 \\
$\mathrm{Ca} / \mathrm{Cl}$ & 0.90 & 0.83 & 0.87 & & 0.56 & 0.50 & 0.52 \\
$\mathrm{~K} / \mathrm{Cl}$ & 0.05 & 0.06 & 0.05 & & 0.03 & 0.03 & 0.03 \\
$\mathrm{Ca} / \mathrm{SO}_{4}$ & 0.14 & 0.10 & 0.12 & & 0.13 & 0.12 & 0.12 \\
\hline
\end{tabular}


Table 3 Correlation coefficient $(R)$ for different parameters during dry season $(n=5)$ in the open-pit groundwater OPGW) in O'Kiep

\begin{tabular}{|c|c|c|c|c|c|c|c|c|c|c|}
\hline Chemistry parameters & COD & Colour & Turbidity & $\mathrm{pH}$ & Temperature & $\mathrm{EC}$ & TDS & DO & Salinity & ORP \\
\hline COD & 1 & & & & & & & & & \\
\hline Colour & 0.6 & 1 & & & & & & & & \\
\hline Turbidity & 0.6 & 0.6 & 1 & & & & & & & \\
\hline $\mathrm{pH}$ at $25^{\circ} \mathrm{C}$ & -1.0 & -0.2 & -0.8 & 1 & & & & & & \\
\hline Temperature & -1.0 & 0.1 & -0.7 & 0.9 & 1 & & & & & \\
\hline $\mathrm{EC}$ & 1.0 & 0.2 & -0.5 & 0.4 & 0.7 & 1 & & & & \\
\hline TDS & 0.3 & 0.2 & -0.5 & 0.4 & 0.7 & 1.0 & 1 & & & \\
\hline DO & 1.0 & 0.4 & -0.5 & 0.6 & 0.9 & 0.8 & 0.8 & 1 & & \\
\hline Salinity & 0.4 & 0.2 & -0.5 & 0.4 & 0.7 & 1.0 & 1.0 & 0.7 & 1 & \\
\hline Redox (ORP) & 1.0 & 0.5 & -0.5 & -0.8 & -0.5 & -0.2 & -0.2 & -0.1 & 1.0 & 1 \\
\hline Cation and anion parameters & $\mathrm{Ca}^{+}$ & $\mathrm{Na}^{+}$ & $\mathrm{Mg}^{2+}$ & $\mathrm{K}^{+}$ & $\mathrm{F}^{+}$ & $\mathrm{Cl}^{-}$ & $\mathrm{SO}_{4}{ }^{2-}$ & $\mathrm{NH}_{3}$ & $\mathrm{P}$ & \\
\hline Calcium $(\mathrm{Ca})$ & 1 & & & & & & & & & \\
\hline Sodium $(\mathrm{Na})$ & 0.7 & 1 & & & & & & & & \\
\hline Magnesium (Mg) & 0.5 & 1.0 & 1 & & & & & & & \\
\hline Potassium (K) & 0.5 & 0.7 & 1.0 & 1 & & & & & & \\
\hline Fluoride $\left(\mathrm{F}^{-}\right)$ & 0.3 & -0.2 & -0.2 & -0.1 & 1 & & & & & \\
\hline Chloride $\left(\mathrm{Cl}^{-}\right)$ & 0.6 & 0.9 & 0.9 & 0.8 & -0.1 & 1 & & & & \\
\hline Sulphate $\left(\mathrm{SO}_{4}{ }^{2-}\right)$ & 0.5 & 0.7 & 1.0 & 1.0 & -0.1 & 0.8 & 1 & & & \\
\hline Ammonia $\left(\mathrm{NH}_{3}\right)$ & 0.1 & 0.0 & 0.5 & 0.6 & 0.4 & 0.3 & 0.6 & 1 & & \\
\hline Ortho-phosphate $(\mathrm{P})$ & -0.1 & 0.5 & 0.4 & 0.4 & -0.2 & 0.7 & 0.3 & 0.2 & 1 & \\
\hline Elemental parameters & $\mathrm{Al}$ & $\mathrm{Cd}$ & $\mathrm{Cr}$ & Co & $\mathrm{Cu}$ & $\mathrm{Fe}$ & $\mathrm{Mn}$ & $\mathrm{Ni}$ & $\mathrm{Zn}$ & $\mathrm{CN}$ \\
\hline Aluminium (Al) & 1 & & & & & & & & & \\
\hline Cadmium (Cd) & 0.9 & 1 & & & & & & & & \\
\hline Chromium $(\mathrm{Cr})$ & 1.0 & 1.0 & 1 & & & & & & & \\
\hline Cobalt (Co) & 0.6 & 0.5 & 0.2 & 1 & & & & & & \\
\hline Copper $(\mathrm{Cu})$ & 0.8 & 1.0 & 1.0 & 0.3 & 1 & & & & & \\
\hline Iron $(\mathrm{Fe})$ & 1.0 & 1.0 & -0.2 & 0.2 & 1.0 & 1 & & & & \\
\hline Manganese (Mn) & 0.8 & -0.1 & 0.5 & 1.0 & 0.5 & 0.6 & 1 & & & \\
\hline Nickel (Ni) & 1.0 & 1.0 & 1.0 & 0.4 & 1.0 & 1.0 & 0.6 & 1 & & \\
\hline Zinc (Zn) & 1.0 & 0.0 & -0.1 & 0.0 & -0.2 & -0.3 & 0.0 & -0.1 & 1 & \\
\hline Cyanide $(\mathrm{CN})$ & 0.9 & 0.4 & 0.4 & 0.2 & 0.6 & 0.6 & 0.3 & 0.5 & -0.9 & 1 \\
\hline
\end{tabular}

Bold indicates statistically significant positive correlations

concentration dependence of the metals (Chabukdhara et al. 2017) in the OPGW. Such relationships of various physical parameters and metallic ions are expected due to several hydrochemical reactions, such as ion exchange and oxidation-reduction in a groundwater aquifer system (Chabukdhara et al. 2017).

\section{Conclusion}

This study assessed the seasonal variation of the OPGW quality near a closed metalliferous mine in O' Kiep (South Africa) and to determine its suitability for drinking and irrigation purposes. It was shown that changes in seasons have an influence on the hydrochemical properties of the
OPGW as evidenced by the low DO and COD concentration in both seasons showing prevailing anoxic conditions and deficiency of organic matter in the OPGW. Furthermore, result also indicated that the groundwater was slightly acidic, with high salinity during both the dry and wet season; albeit SAR both seasons showed that the OPGW was suitable for irrigation purpose; however, long-term use may cause damage to the soil. This was also further confirmed by a Mg/ $\mathrm{Ca}$ ratio of less than 1.5. The PHREEQC suggested that the cation exchange played a significant role in controlling the OPGW chemistry with antimony and calcium appearing to be the minerals with the greatest chance of precipitation followed by $\mathrm{Mn}_{2} \mathrm{Sb}$ and AlSb, respectively. The results of the present study provide information that can be useful for water resource management in the O' Kiep area; particularly, 
Table 4 Correlation coefficient $(R)$ for different parameters during wet season $(n=5)$ in the open-pit groundwater OPGW) in O'Kiep

\begin{tabular}{|c|c|c|c|c|c|c|c|c|c|c|}
\hline Chemistry parameters & Turbidity & $\mathrm{pH}$ & Temperature & $\mathrm{EC}$ & TDS & Salinity & ORP & & & \\
\hline Turbidity & 1 & & & & & & & & & \\
\hline $\mathrm{pH}$ at $25^{\circ} \mathrm{C}$ & 0.9 & 1 & & & & & & & & \\
\hline Temperature & 0.2 & 0.5 & 1 & & & & & & & \\
\hline $\mathrm{EC}$ & -1.0 & -0.9 & -0.2 & 1 & & & & & & \\
\hline TDS & 1.0 & 0.9 & 0.0 & -1.0 & 1 & & & & & \\
\hline Salinity & 1.0 & 0.9 & 0.1 & -1.0 & 1.0 & 1 & & & & \\
\hline Redox (ORP) & 1.0 & -0.8 & -0.1 & 0.9 & -1.0 & 1,0 & 1 & & & \\
\hline Cation and anion parameters & $\mathrm{Ca}^{+}$ & $\mathrm{Na}^{+}$ & $\mathrm{Mg}^{2+}$ & $\mathrm{K}^{+}$ & $\mathrm{F}^{+}$ & $\mathrm{Cl}^{-}$ & $\mathrm{SO}_{4}^{2-}$ & $\mathrm{NH}_{3}$ & & \\
\hline Calcium $(\mathrm{Ca})$ & 1 & & & & & & & & & \\
\hline Sodium $(\mathrm{Na})$ & -0.2 & 1 & & & & & & & & \\
\hline Magnesium (Mg) & -0.4 & 1.0 & 1 & & & & & & & \\
\hline Potassium (K) & 0.0 & 0.9 & 0.9 & 1 & & & & & & \\
\hline Fluoride $\left(\mathrm{F}^{-}\right)$ & 0.2 & -0.8 & -0.8 & -0.5 & 1 & & & & & \\
\hline Chloride $\left(\mathrm{Cl}^{-}\right)$ & 0.1 & 0.1 & 0.1 & 0.5 & 0.5 & 1 & & & & \\
\hline Sulphate $\left(\mathrm{SO}_{4}{ }^{2-}\right)$ & -0.2 & 1.0 & 1.0 & 0.9 & -0.8 & 0.1 & 1 & & & \\
\hline Ammonia $\left(\mathrm{NH}_{3}\right)$ & -0.3 & 0.1 & 0.2 & -0.3 & -0.7 & -1.0 & 0.1 & 1 & & \\
\hline Elemental parameters & $\mathrm{Al}$ & $\mathrm{Cd}$ & $\mathrm{Cr}$ & Co & $\mathrm{Cu}$ & $\mathrm{Fe}$ & $\mathrm{Mn}$ & $\mathrm{Ni}$ & $\mathrm{Zn}$ & $\mathrm{CN}$ \\
\hline Aluminium (Al) & 1 & & & & & & & & & \\
\hline Cadmium (Cd) & -0.6 & 1 & & & & & & & & \\
\hline Chromium (Cr) & 0.3 & -0.4 & 1 & & & & & & & \\
\hline Cobalt (Co) & 0.7 & -0.1 & -0.5 & 1 & & & & & & \\
\hline Copper $(\mathrm{Cu})$ & -0.1 & 0.3 & -1.0 & 0.6 & 1 & & & & & \\
\hline Iron $(\mathrm{Fe})$ & -0.5 & 0.2 & -0.1 & 0.1 & 0.8 & 1 & & & & \\
\hline Manganese (Mn) & 0.9 & 0.1 & 0.6 & 0.3 & -0.5 & -0.6 & 1 & & & \\
\hline Nickel (Ni) & 1.0 & -0.7 & 0.2 & 0.7 & 0.0 & -0.3 & 0.9 & 1 & & \\
\hline Zinc (Zn) & 1.0 & -0.6 & 0.4 & 0.6 & -0.2 & -0.6 & 0.9 & 0.9 & 1 & \\
\hline Cyanide (CN) & 0.9 & -0.7 & -0.1 & 0.8 & 0.2 & 0.0 & 0.7 & 1.0 & 0.8 & 1 \\
\hline
\end{tabular}

Bold indicates statistically significant positive correlations

with respect to biodiversity changes due to anthropogenic effects. Based on these results, a water treatment system is recommended as a remedial measure for the contaminated OPGW in O'Kiep.

Acknowledgements The authors are grateful to sponsorship from the North-West University, from the Cape Peninsula University of Technology (CPUT) University Research Fund (Grant no. URF RY12) and the National Research Foundation (NRF) in South Africa, Research Grants Thuthuka 2019 (Grant No. TTK180409318662, 94152). We thank Mr Denzil Bent for assistance with geochemical modelling that greatly improved the manuscript.

\section{References}

Abdelgawad A (2005) Mineralogical and morphological features of fractured granitic rock tested under water-rock interaction. In: Eighteenth international water technology conference, IWTC18: 12-14 March 2015

Abdi H (2010) Coefficient of variation. Encycl Res Des 1:169-171
Abiye T, Bybee G, Leshomo J (2018) Fluoride concentrations in the arid Namaqualand and the Waterberg groundwater, South Africa: understanding the controls of mobilization through hydrogeochemical and environmental isotopic approaches. Groundw Sustain Dev 6:112-120

Abiye TA, Leshomo JT (2013) Groundwater flow and radioactivity in Namaqualand, South Africa. Environ Earth Sci 70:281-293

Accuweather 2017. https://www.accuweather.com/en/za/okiep/29993 8/month/299938?monyr=4/01/2017. Accessed 10 Aug 2017

Adams S, Jovanovic N, Thomas A, Titus R, Anthony R, Majola A, Jia H (2004) Review of groundwater vulnerability assessment methods-unsaturated zone. University of the Western Cape, Bellville, p 17

Adams S, Titus R, Xu Y (2003) Groundwater recharge assessment of the basement aquifers of central Namaqualand. University of the Western Cape, Cape Town

Antonijević M, Dimitrijević M, Stevanović Z, Serbula SM, Bogdanovic GD (2008) Investigation of the possibility of copper recovery from the flotation tailings by acid leaching. J Hazard Mater 158:23-34

APHA (2005) Standard methods for the examination of water and waste water. American Journal of Public Health, Washington DC 
Appelo CAJ, Postma D (2004) Geochemistry, groundwater and pollution. CRC Press, Boca Raton

Ball JW, Nordstrom DK, McCleskey RB, To TBA (1999) New method for the direct determination of dissolved Fe (III) concentration in acid mine waters. In: US Geological Survey Toxic Substances Hydrology Program-proceedings of the technical meeting, Charleston, SC, pp 297-304

Beale CO (1985) Copper in South Africa-Part 1. J South Afr Inst Min Metall 85(3):73-80. https://www.saimm.co.za/Journal/v085n 03p073.pdf. Accessed 26 Feb 2020

Bosire GO, Ngila JC, Nkambule TTI (2018) Geochemical scaling potential simulations of natural organic matter complexation with metal ions in cooling water at Eskom power generation plants in South Africa. Water SA 44(4):706-718. https://doi.org/10.4314/ wsa.v44i4.19 (ISSN 1816-7950)

Braune E, Xu Y (2010) The role of ground water in Sub-Saharan Africa. Groundwater 48:229-238

Bredenhann L, Braune E (2000) Policy and strategy for groundwater quality management in South Africa. Department of Water Affairs and Forestry

Brindha K, Pavelic P, Sotoukee T, Douangsavanh S, Elango L (2017) Geochemical characteristics and groundwater quality in the Vientiane Plain, Laos. Expos Health 9:89-104

Cairncross B (2004) History of the O'Kiep Copper District Namaqualand, Northern Cape Province South Africa. Mineral Rec 35:289

Chabukdhara M, Gupta SK, Kotecha Y, Nema AK (2017) Groundwater quality in Ghaziabad district, Uttar Pradesh, India: multivariate and health risk assessment. Chemosphere 179:167-178

Cho BW, Choo CO (2019) Geochemical behavior of uranium and radon in groundwater of Jurassic Granite Area, Icheon, Middle Korea. Water 11:1278

Clifford TN, Barton ES (2012) The O'okiep Copper District, Namaqualand, South Africa: a review of the geology with emphasis on the petrogenesis of the cupriferous Koperberg Suite. Miner Depos 47:837-857

Coyte RM, Singh A, Furst KE, Mitch WA, Vengosh A (2019) Cooccurrence of geogenic and anthropogenic contaminants in groundwater from Rajasthan, India. Sci Total Environ 688:1216-1227

DWAF (1996) Department of Water Affairs and Forestry: South African water quality guidelines, vol 1, Domestic Water Use, 2nd edn. Pretoria

DWA (2004) Department of water affairs: integrated water resource management strategies, guidelines and pilot implementation in three water management arears. Government Gazzette, Pretoria

Dinicola RS (2006) Continued biodegradation of chloroethene compounds in ground water at Operable Unit 1, Naval Undersea Warfare Center, Division Keyport, Washington: U.S. Geological Survey Scientific Investigations Report 2006-5056

Edet A, Okereke C (2002) Delineation of shallow groundwater aquifers in the coastal plain sands of Calabar area (Southern Nigeria) using surface resistivity and hydrogeological data. J Afr Earth Sci 35:433-443

Edmunds WM, Shand P (2009) Natural groundwater quality. Wiley, Hoboken

Erdogan IG, Bent D, Ntwampe SKO, Fosso-Kankeu E, Waanders FB (2019) Geochemical modelling and seasonal hydrogeochemical processes of the open-pit groundwater at O'Kiep, Namaqualand, South Africa. https://doi.org/10.25381/cput.9746537.v1. Accessed 29 Aug 2019

Erdogan IG, Fosso-Kankeu E, Ntwampe SKO, Waanders FB, Hoth N, Randb A (2018) Potential toxic elements contamination of soils in O'Kiep, an arid region of Namaqualand, South Africa. In: 10th Int'l conference on advances in science, engineering, technology \& healthcare (ASETH-18) Nov. 19-20, 2018 Cape Town, South Africa. https://doi.org/10.17758/EARES4.EAP1118238
Erdogan I, Moncho T, Fosso-Kankeu E, Ntwampe S, Waanders F, Hoth N, Rand A, Fourie B (2017) Hydrochemical characteristics of open-pit groundwater from a closed metalliferous mine in O'kiep, Namaqualand Region, South Africa. In: 9th Int'l conference on advances in science, engineering, technology and waste management (ASETWM-17) Nov. 27-28, pp 64-68. https://doi.org/10.17758/EARES.EAP1117022.

Faris N, Ram R, Chen M, Tardio J, Pownceby MI, Jones LA, McMaster S, Webster NA, Bhargava S (2017) The effect of thermal pre-treatment on the dissolution of chalcopyrite $(\mathrm{CuFeS} 2)$ in sulfuric acid media. Hydrometallurgy 169:68-78

Ferreira S, Meyer S, Vivier J (2015) Environmental impact impact assessment RVM 1 hydroelectric power (Pty) Ltd Riemvasmaak Hydropower Project, Orange River, Northern Cape Province, South Africa. Accessed 10 July 2019

Fisher RS, Mullican I, William F (1997) Hydrochemical evolution of sodium-sulfate and sodium-chloride groundwater beneath the Northern Chihuahuan Desert, Trans-Pecos, Texas, USA. Hydrogeol J 5:4-16

Fosso-Kankeu E, Manyatshe A, van der Berg D, Lemmer N, Waanders F, Hlanganani T (2015) Contaminants in sediments across the mooi and vaal rivers network in the vicinity of Potchefstroom. In: 7th International conference on latest trends in engineering and technology (ICLTET'2015)

Fosso-Kankeu E, Manyatshe A, Waanders F (2017) Mobility potential of metals in acid mine drainage occurring in the Highveld area of Mpumalanga Province in South Africa: implication of sediments and efflorescent crusts. Int Biodeterior Biodegrad 119:661-670

Gibs J, Wilde F D (2007) Use of Multiparameter 6.8 instrument for routine filed measurements. https://pdfs.semanticscholar .org/1e96/0aa07af7a7fc8dcc81400bc659aaf4 1be7ef.pdf. Accessed 26 Feb 2020

Güler C, Thyne GD, McCray JE, Turner KA (2002) Evaluation of graphical and multivariate statistical methods for classification of water chemistry data. Hydrogeol J 10:455-474

Hangone G, Bradshaw D, Ekmekci Z (2005) Flotation of a copper sulphide ore from Okiep using thiol collectors and their mixtures. J S Afr Inst Min Metall 105:199-206

Harilal C, Hashim A, Arun P, Baji S (2004) Hydrogeochemistry of two rivers of Kerala with special reference to drinking water quality. Ecol Environ Conserv 10:187-192

Holmes S (ed) (1995) Department of Water Affairs and Forestry: South African water quality guidelines. Pretoria: Government Gazette. https://www.cesnet.co.za/pubdocs/Kamiesberg\%20Heavy\%20 Minerals\%20Mining\%20249CB/Surface\%20and\%20Groundwa ter\%20Assessment.pdf. Accessed 10 Aug 2019

Iwatsuki T, Furue R, Mie H, Ioka S, Mizuno T (2005) Hydrochemical baseline condition of groundwater at the Mizunami underground research laboratory (MIU). Appl Geochem 20:2283-2302

Jeevanandam M, Kannan R, Srinivasalu S, Rammohan V (2007) Hydrogeochemistry and groundwater quality assessment of lower part of the Ponnaiyar River Basin, Cuddalore district, South India. Environ Monit Assess 132:263-274

Jonch-Clausen T (2004) Integrated water resources management (IWRM) and water efficiency plans by 2005": why, what and how? Global Water Partnership Stockholm. Accessed 12 Aug 2019

Kumar M, Ramanathan A, Rao MS, Kumar B (2006) Identification and evaluation of hydrogeochemical processes in the groundwater environment of Delhi, India. Environ Geol 50:1025-1039

Larkins C, Turunen K, Mänttäri I, Lahaye Y, Hendriksson N, Forsman P, Backnäs S (2018) Characterization of selected conservative and non-conservative isotopes in mine effluent and impacted surface waters: implications for tracer applications at the mine-site scale. Appl Geochem 91:1-13 
Lee JY, Choi JC, Yi MJ, Kim JW, Cheon JY, Choi YK, Choi MJ, Lee KK (2005) Potential groundwater contamination with toxic metals in and around an abandoned Zn Mine, Korea. Water Air Soil Pollut 165:167-185

Leonard K, Pierre G (2013) Modeling groundwater flow and quality. https://doi.org/10.1007/978-94-007-4375-5_33

Leshomo J (2011) Investigation of hydrochemistry and uranium radioactivity in the groundwater of Namaqualand, Northern Cape, South Africa, Johannesburg: MSc Thesis, University of Witwatersrand

Ma X, Chen Y, Zhu C, Li W (2011) The variation in soil moisture and the appropriate groundwater table for desert riparian forest along the Lower Tarim River. J Geogr Sci 21:150-216

Manoj S, Thirumurugan M, Elango L (2017) An integrated approach for assessment of groundwater quality in and around uranium mineralized zone, Gogi region, Karnataka, India. Arab J Geosci 10:557

Mativenga PT, Marnewick A (2018) Water quality in a mining and water-stressed region. J Clean Prod 171:446-456

Mladenov N, Wolski P, Hettiarachchi GM, Murray-Hudson M, Enriquez H, Damaraju S, Galkaduwa MB, McKnight DM, Masamba W (2014) Abiotic and biotic factors influencing the mobility of arsenic in groundwater of a through-flow island in the Okavango Delta, Botswana. J Hydrol 518:326-341

Moncho T, Erdogan I, Emandien M, Ntwampe S, Fosso-Kankeu E, Waanders F, Rand A, Fourie B (2017) Prediction of metals bioavailability in the soils of O'kiep, South Africa. In: 9th Int'l conference on advances in science, engineering, technology and waste management (ASETWM-17) Nov. 27-28, 29, 17.879916. https://doi.org/10.17758/EARES.EAP1117023

Morrel I, Pulido-Bosch A, Fernandez R (1986) Rubio, hydro geochemical analysis of salinization processes in the coastal aquifers of Oropesa, Spain. Environ Geol 29:118-131

Munyai A, Fosso-Kankeu E, Waanders F (2016) Mobility of metals from mine tailings using different types of organic acids: batch leaching experiment. Int J Sci Res 5:520-527

Nakwafila AN (2015) Salinisation source (s) and mechanism (s) in shallow alluvial aquifers along the Buffels River, Northern Cape Province, South Africa. Stellenbosch University, Stellenbosch

Nordstrom DK, Wilde FD (2005) Reduction-6.5 oxidation potential (electrode method). National field manual for the collection of water-quality data. http://www.caslab.com/Test-Methods-Search/ PDF/USGS-Method-NFM-65.pdf. Accessed 26 Feb 2020

Northern Cape Department of Environmental Affairs and Nature Conservation (2018). https://www.northern-cape.gov.za/denc/index .php/nature-reserves/goegap. Accessed 2 Dec 2019

Nuclear (2006). https://www.eskom.co.za/OurCompany/Sustainabl eDevelopment/EnvironmentalImpactAssessments/Documents/ Nuclear_1_FSR_Ch_6_pgs_89-1071.pdf. Accessed 10 Aug 2017

Nwankwoala $\mathrm{H}$, Udom G (2011) Hydrochemical facies and ionic ratios of groundwater in Port Harcourt, Southern Nigeria. Res J Chem Sci 1:87-101

Osborne MR (2009) Biological wastewater treatment and reactive nitrogen: history, microbiology, health and environmental considerations. MSc Thesis. University of Maryland, Maryland

Ouyang Y, Zhang JE, Cui L (2014) Estimating impacts of land use on groundwater quality using trilinear analysis. Environ Monit Assess 186:5353-5362

Pacheco Castro R, Pacheco Ávila J, Ye M, Cabrera Sansores A (2018) Groundwater quality: analysis of its temporal and spatial variability in a karst aquifer. Groundwater 56:62-72

Parkhurst DL, Appelo C (1999) User's guide to PHREEQC (Version $2)$ : a computer program for speciation, batch-reaction, onedimensional transport, and inverse geochemical calculations. Water Resour Investig Rep 99:312
Pietersen K, Titus R, Cobbing J (2009) Effective groundwater management in namaqualand: sustaining supplies. Water Research Commission, Pretoria

Plumlee GS (1999) The environmental geology of mineral deposits. In: The environmental geochemistry of mineral deposits. Society of Economic Geologists. Part A, pp 71-116

Praveena SM, Abdullah MH, Bidin K, Aris AZ (2011) Understanding of groundwater salinity using statistical modeling in a small tropical island, East Malaysia. Environmentalist 31:279

Pretorius J, Usher B, Gebrekristos R (2008) Groundwater monitoring guidelines for DNAPLs in South African aquifers. Citeseer, Princeton

Purandara B, Varadarajan N, Jayashree K (2003) Impact of sewage on ground water quality - a case study. Pollut Res 22:189-197

Quevauviller P, Fouillac AM, Grath J, Ward R (2009) Groundwater monitoring. Wiley-Blackwell, Hoboken

Rabbani MG, Rahman A, Islam N (2010) Climate change and sea-level rise: issues and Challenges for coastal communities in the Indian Ocean region. In: Michel D, Pandya A (eds) Coastal zone and climate change. The Henry L Stimson Center, Washington, pp $17-29$

Raith JG, Cornell DH, Frimmel HE, De Beer CH (2003) New insights into the geology of the Namaqua tectonic province, South Africa, from ion probe dating of detrital and metamorphic zircon. J Geol 111:347-366

Rajendran R, Emerenshiya CA, Dheenadayalan MS (2019) Investigations on groundwater quality in Tiruchirappalli city, Tamilnadu, India. Sustain Water Resour Manag 5(2):599-609

Ramakrishnaiah C, Sadashivaiah C, Ranganna G (2009) Assessment of water quality index for the groundwater in Tumkur Taluk, Karnataka State, India. J Chem 6:523-530

Ramos OER, Rötting TS, French M, Sracek O, Bundschuh J, Quintanilla J, Bhattacharya P (2014) Geochemical processes controlling mobilization of arsenic and trace elements in shallow aquifers and surface waters in the Antequera and Poopó mining regions, Bolivian Altiplano. J Hydrol 518:421-433

Rao NS (2006) Seasonal variation of groundwater quality in a part of Guntur District, Andhra Pradesh, India. Environ Geol 49:413-429

Reddy D, Nagabhushanam P, Sukhija B, Reddy A, Smedley P (2010) Fluoride dynamics in the granitic aquifer of the Wailapally watershed, Nalgonda District, India. Chem Geol 269:278-289

Riedel T, Kübeck C (2018) Uranium in groundwater-a synopsis based on a large hydrogeochemical data set. Water Res 129:29-38

Rijal ML, Appel E, Petrovský E, Blaha U (2010) Change of magnetic properties due to fluctuations of hydrocarbon contaminated groundwater in unconsolidated sediments. Environ Pollut $158: 1756-1762$

Roets W (2008) Groundwater dependence of aquatic ecosystems associated with the table mountain group aquifer. University of the Western Cape, Cape Town

Sahraei Parizi H, Samani N (2013) Geochemical evolution and quality assessment of water resources in the Sarcheshmeh copper mine area (Iran) using multivariate statistical techniques. Environ Earth Sci 69:1699-1718

SANS241-1 (2015) South African National Standard (SANS 241-1): 2015. Drinking water. Part 1. Microbial, physical, aesthetic and chemical determinants, 2 edn. Pretoria

Selvakumar S, Chandrasekar N, Kumar G (2017) Hydrogeochemical characteristics and groundwater contamination in the rapid urban development areas of Coimbatore, India. Water Resour Ind 17:26-33

Shah D, Mjalli FS (2014) Effect of water on the thermo-physical properties of Reline: an experimental and molecular simulation based approach. Phys Chem Chem Phys 16(43):23900-23907 
Shen S, Ma T, Du Y, Luo K, Deng Y, Lu Z (2019) Temporal variations in groundwater nitrogen under intensive groundwater/surfacewater interaction. Hydrogeol J 27(5):1753-1766

Shorieh A, Porel G, Razack M (2015) Assessment of groundwater quality in the dogger aquifer of poitiers, Poitou-Charentes Region, France. J Water Resour Prot 7:171

Singh G, Kamal RK (2015) Assessment of groundwater quality in the mining areas of Goa, India. Indian J Sci Technol 8:588

Singh KP, Malik A, Sinha S (2005) Water quality assessment and apportionment of pollution sources of Gomti river (India) using multivariate statistical techniques-a case study. Anal Chim Acta 538:355-374

Stanković S, Morić I, Pavić A, Vojnović S, Vasiljević B, Cvetković V (2015) Bioleaching of copper from samples of old flotation tailings (Copper Mine Bor, Serbia). J Serbian Chem Soc 80:391

Sundaram B, Feitz A, de Caritat P, Plazinska A, Brodie R, Coram J, Ransley T (2009) Groundwater sampling and analysis-a field guide. Geosci Aust Rec 27:95

Tikhomirov VV (2016) Hydrogeochemistry fundamentals and advances, mass transfer and mass transport. Wiley, Hoboken

Titus R (2002) Groundwater assessment and strategies for sustainable resource supply in arid zones: the Namaqualand case study. Water Research Commission, Pretoria

Tomlinson DW, Rivett MO, Wealthall GP, Sweeney RE (2017) Understanding complex LNAPL sites: illustrated handbook of LNAPL transport and fate in the subsurface. J Environ Manag 204:748-756

Trick JK, Stuart M, Reeder S (2008) Contaminated groundwater sampling and quality control of water analyses. Environmental geochemistry: site characterization, data analysis and case histories. Elsevier, Amsterdam, pp 29-57

Van Dyk G, Makhetha J, Potgieter D, Zikali T, Leeme V, Moletsane F, Vonya T (2008) Groundwater resources in the Northern Cape Province 2008. Department Water Affairs and Forestry, Kimberley

Van Wyk I, Roychoudhury A, Maherry A, Genthe B (2012) Hydrogeochemical characterisation and evaluation of groundwater resources and review of groundwater management schemes in Kamiesberg, Northern Cape
Weaver JM, Cave L, Talma AS (2007a) Groundwater sampling. Water Research Commission Report No. TT. Water Research Commission, Gezina

Weaver JM, Cavé LC, Talma AS (2007) Groundwater sampling: a comprehensive guide for sampling methods. Water Research Commission, Gezina

Whitworth KL, Silvester E, Baldwin DS (2014) Alkalinity capture during microbial sulfate reduction and implications for the acidification of inland aquatic ecosystems. Geochim Cosmochim Acta 130:113-125

WHO (2011) Guidelines for drinking-water quality. World Health Organisation, Geneva

WHO (2017) Water quality and health-review of turbidity: information for regulators and water suppliers. World Health Organization, Geneva

Wilde FD, Radtke DB (1998) Handbooks for water-resources investigations: national field manual for the collection of water-quality data. Field measurements, US Department of the Interior, US Geological Survey

$\mathrm{Xu}$ Y, Braune E (2009) Groundwater resources in Africa. Sustainable groundwater resources in Africa. CRC Press, Boca Raton

Yan S, Yu S, Wu Y, Pan D, She D, Ji J (2015) Seasonal variations in groundwater level and salinity in coastal plain of eastern China influenced byclimate. J Chem. https://doi. org/10.1155/2015/905190

Zheng Y, Stute M, Van Geen A, Gavrieli I, Dhar R, Simpson H, Schlosser P, Ahmed K (2004) Redox control of arsenic mobilization in Bangladesh groundwater. Appl Geochem 19:201-214

Zhu C, Anderson G (2002) Environmental applications of geochemical modeling. Cambridge University Press, Cambridge

Publisher's Note Springer Nature remains neutral with regard to jurisdictional claims in published maps and institutional affiliations. 